\title{
УДК: 72.033
}

ББК: $85.113(4)$

DOI: $10.18688 / \mathrm{aa} 2111-04-36$

\author{
М. Л. Заворина
}

\section{Эпирская традиция в поздневизантийской архитектуре Северной Македонии ${ }^{1}$}

Региональное своеобразие и взаимовлияние отдельных центров - проблема, вокруг которой строится дискуссия поздневизантийского зодчества (1204-1453) [4; 5; 10; 11 ; $16 ; 18 ; 25 ; 26 ; 27 ; 28]$. Особое значение она имеет для архитектурных процессов на периферии Византийской империи, в частности, на территории современной Северной Македонии, примерно совпадающей с границами Охридской архиепископии XIII-XIV вв. (Охридско-Преспанский регион, Пелагония). Специфика исторического развития этого региона - сосуществование славянской и греческой культур, нестабильная политическая ситуация в XIII в., сделавшая Македонию ареной столкновения Эпира, Никеи, Болгарии и Сербии, привела к активному взаимодействию и смешению архитектурных традиций. Поиск истоков поздневизантийского зодчества Северной Македонии и обоснование его принадлежности той или иной архитектурной традиции стали главными аспектами изучения этого материала с начала XX в. [7; 8; 23]. Однако ясной объективной картины до сих пор не сложилось. Появление множества бездоказательных гипотез и противоречивых суждений во многом связано с тем, что мотивацией для изучения средневекового наследия Северной Македонии стали национальные интересы представителей сербской, болгарской, греческой, а позже и македонской исследовательских школ $[1 ; 5 ; 10 ; 26]$, вызванные не затихающим по сей день «Македонским вопросом» [3].

В последнюю четверть XIII в. в Охриде и Прилепе после продолжительного периода стагнации появляется группа памятников, связанных с архитектурными практиками Эпира. И хотя отдельные черты эпирской школы в поздневизантийских храмах Северной Македонии отмечались исследователями и ранее [19], только с 1980-х гг. их стали рассматривать в широком кругу влияния Эпира $[10 ; 17$, р.562-576, 600-602; 22; 26; 27; 28]. Продолжение эпирской традиции в архитектуре Македонии как самостоятельная проблема формулируется в статье С. Чурчича: он не только расширил и уточнил круг памятников, но и поднял вопрос об идентификации отдельных эпирских мастерских, работавших в этом регионе [18]. Однако особенности стилистического развития и механизмов ассимиляции эпирской традиции в Северной Македонии, уточнение места македонских памятников в контексте широких архитектурных процессов поздневизантийского периода - вопросы, которые до сих пор не получили последовательного ре-

1 Исследование выполнено в рамках Плана фундаментальных научных исследований РААСН и Минстроя России на 2021 год, тема № 1.1.1.2. 
зультативного осмысления. К этим аспектам мы намерены обратиться в рамках данной статьи.

Для начала необходимо дать достаточное представление об архитектуре Эпира. В эпоху латинского господства (1204-1261) в условиях общей стагнации строительство на византийских Балканах продолжалось в Эпирском деспотате, возглавляемом династией Комнино-Дуков - главных соперников императоров Никеи в борьбе за будущую корону Византийской империи [24, p.49-64]. В 1230-1260-е гг. здесь складывается местная архитектурная школа, которая при укоренённости в предшествующей традиции элладской и доэлладской школ представляется ярким региональным явлением, обладающим набором характерных черт [17, р. 562-576, 600-602; 26; 27]. Преобладающим типом становятся небольшие однонефные базилики с деревянной кровлей (ц. Панагии в Превентзе (вт. пол. XIII в.), ц. Св. Василия в Арте (к. XIII в.)). Среди различных вариантов крестово-купольного типа особо примечателен так называемый двухколонный тип, с применением двух разных пар опор - алтарных стенок с востока и колонок с запада (ц. Св. Николая Родиас (нач. XIII в.), ц. Панагии в Вулгарели, 1295 г.). Активное развитие в эпирской школе получил тип ставроэпистегос, особенность которого состоит в конструкции перекрытий: купол на пересечении рукавов креста замещён повышенным цилиндрическим сводом (церковь Панагии Бриони (1238) и Като-Панагия близ Арты (сер. XIII в.), церковь Таксиархов в Костаниани (вт. пол. XIII в), Св. Димитрия в Кипсели (1296-1318)) [21].

К устойчивым морфологическим особенностям относятся гранёные барабаны куполов, нередко с каменными колонками по углам, трёхгранные апсиды, артикулированные слепыми арками, треугольные фронтоны, часто повышенные, а также очень характерное обрамление окон трёхлопастной композицией из полуциркульной арки с двумя примыкающими к ней четвертными. В региональной практике закрепились пространственно обособленные от наоса трёхтравейные нартексы (Св. Николай Родиас (нач. XIII в.), Св. Феодора в Арте (1270-е гг.), Панагия в Вулгарели (1295 г.)), а со второй половины XIII в. в соответствии с общими тенденциями палеологовского зодчества получает распространение обстройка основного объёма галереями.

Артикуляция фасадов эпирских храмов ограничивается выделением сводов рукавов креста или сводов нартекса невысокими чуть заглублёнными арочными нишами и активным использованием поясков поребика, проложенных с двух сторон плинфой. Ниже уровня сводов преобладает массивный нерасчленённый призматический объём, декорированный горизонтальными поясами керамопластических орнаментов. Эти свойства характеризуют стилистическую парадигму Эпира, выведенную С. Чурчичем [17, p. 600602]. Яркой особенностью эпирского зодчества стал широкий видовой и иконографический декоративный вокабуляр: разнообразные паттерны из простого и вырезного кирпича, широкие полосы кладки опус ретикулатум и опус спикатум, псевдомеандры, поливная керамика и рельефы, фиалостомии, кирпичные ктиторские надписи [22; 25 , p. 14-27, 138-140; 28]. Декоративными свойствами обладает и техника кладки клуазоне, которая встречается здесь в двух вариантах [27, p. 84-85].

В эволюции эпирского зодчества можно выделить три этапа. При первых Комнино-Дуках (1205-1230-е) ещё прочна связь с элладской школой: отмечается простота 
и лаконичность форм, развитие традиционных типов, скупость фасадного декора. Правление Михаила II (1231-1268) - время окончательного сложения и главных достижений эпирской школы: появляются новые типологические решения, разрабатывается морфология, усложняется декор фасадов, прослеживаются влияния столичной (константинопольско-никейской) и западноевропейской архитектурных традиций. Наконец, во время Никифора I и его преемников (1268-1310-е) зодчество Эпира развивается уже в русле тенденций палеологовского периода: характерны стандартизация и упорядочивание декоративных программ, изменение в трактовке формы в сторону большей пластичности, усиление влияния Южной Италии, проявившееся в заимствовании декоративных элементов (архитектурная скульптура и поливная керамика итальянского производства) и коснувшееся иконографии архитектуры (церковь Паригоритиссы в Арте, 1294-1296), обстройка основного объёма периферийными зонами. Эта раннепалеологовская фаза соответствует времени появления построек с чертами эпирской архитектуры в македонских региональных центрах - в Охриде и Прилепе, что даёт основание рассматривать македонское направление в контексте палеологовской архитектуры Эпира.

После реставрации Империи, в последние десятилетия XIII в. архитектурная традиция Эпира вместе с миграцией строительных артелей распространилась за пределы деспотата, став одним из источников формирования палеологовского стиля в Константинополе и в региональных центрах Эгейской Македонии (Салоники, Верия, Кастория). На северных окраинах Византии новым очагом строительной активности становится Охрид - центр автокефальной архиепископии, занимавшей особое место в политических, церковно-идеологических и культурных процессах и оказывавшей активную поддержку эпирским деспотам в их противостоянии с Никейской империей [24, p. 49-64]. В 1280-1310-е гг. в Охриде появляются три постройки, которые исследователи связывали с работой трёх разных строительных артелей [18; 19].

Церковь Св. Иоанна Богослова Канео датируют 70-80-ми гг. XIII в. [10, с. 84-90, 195200; 12; 17 р. 572-574; 18] (Илл. 98). Это храм типа вписанного креста, слегка вытянутый по продольной оси за счёт удлинения западной травеи, без нартекса. Купол опирается на две разные пары опор: с востока это прямоугольные участки алтарных стенок, с запада - невысокие столбы со срезанными углами и профилированными завершениями, напоминающими псевдокапители. Близкие по форме опоры встречаются в Эпире (ц. Успения в Парамитье, ц. Таксиархов в Костаниани), но в данном случае такое сочетание опор позволяет рассматривать применённое здесь решение как видоизменённый двухколонный тип элладской и эпирской школ [10, с. 195]. Во внешнем облике постройки ясно прочитываются рукава креста, артикулированные на эпирский манер вписанными в треугольные фронтоны плоскими полуциркульными нишами. Декор сосредоточен на восточном фасаде: в верхней части трёхгранной апсиды проходит широкий фриз опус ретикулатум, ниже - три невысокие плоские ниши с тройными профилировками, обведённые проложенным с двух сторон плинфой поребриком и заполненные простыми кирпичными орнаментами. Интересно решение барабана купола: грани оформлены слепыми арками в один уступ, с выложенными плинфой двойными архивольтами, и разделены каменными колонками. Такой тип барабана, известный как «афинский», хорошо известен по средневизантийским памятникам центральной Греции [10, с. 251- 
252]. Специфическая черта - декорация венчающих частей барабана миниатюрными эпирскими трёхлопастными арочками и завершение граней треугольными щипцами, подлинность которых вызывает вопрос [12; 17, p. 574].

Церковь Св. Иоанна Канео С. Чурчич связал с северо-эпирской группой памятников, а именно - с Бератом, но без указания конкретных сходств. Отчасти мы согласны с этой точкой зрения. Отсутствие подпружных арок в боковых нефах, техника кладки, расположение узких порталов по трём сторонам со сдвигом по оси, двухколонный тип - всё это обнаруживает сходство с церковью Св. Троицы в Берате (к. XIII в.). Артикуляция барабана слепыми арками с двойными архивольтами появляется в небольшой церкви Св. Спаса в Борье близ Корче (к. XIII - нач. XIV в.) в Албании. Достаточно и различий, главным из которых, на наш взгляд, является сам характер построек: в Берате и Борье это сильно провинциализированная и упрощённая эпирская школа, в Канео - качественный и довольно оригинальный, но архаизированный вариант при обращении не столько к актуальной архитектуре Эпира 1270-80-х гг., сколько к элладской школе. Помимо «афинского» типа купола, черты элладской школы можно отметить в декорации апсиды широким фризом опус ретикулатум (аналогичный пример - ц. Свв. Сергия и Вакха в Китте, Пелопоннес, 3-я четверть XII в.), в разделке граней апсиды равновысокими плоскими нишами (самый ранний пример - ц. Св. Димитрия в Эани, Западная Македония, до XIII в.).

Один из превосходных образцов поздневизантийского зодчества - церковь Богородицы Перивлепты, построенная в 1295 г. византийским аристократом Прогоном Згуром [10, с.91-100; 19; 20, р. 176; 46] (Илл. 99). Основные типологические и морфологические характеристики схожи с церковью Св. Иоанна с той лишь разницей, что в Перивлепте появляется обособленный трёхчастный нартекс, хорошо знакомый эпирской школе. Внешне не артикулированный простой гладкий призматический объём, опоясанный псевдомеандром и лентой опус ретикулатум, оформление сводов рукавов креста плоскими полуциркульными нишами, вписанными в треугольные фронтоны, высокая трёхгранная апсида и гранёный барабан с трёхуступчатыми слепыми арками, обведёнными прослоённым с двух сторон плинфой поребриком, - всё это безошибочно определяет эпирскую традицию в финальной стадии её развития (1280-1310-е гг.), соответствующей раннепалеологовскому периоду. Композиционное мастерство, проявившееся как в структурном и пропорциональном соотношении отдельных элементов, так и в декорации фасадов, высокое качество исполнения указывает на происхождение мастеров из столицы деспотата, которое подтверждается и близким сходством Перивлепты с церковью Панагии в Вулгарели близ Арты, отмеченное ещё Х. Халленслебеном, предположившим, что оба храма - результат работы одной и той же артели [19].

В 1313-1314 гг. по заказу архиепископа Григория к собору Св. Софии Охридской был пристроен монументальный двухэтажный экзонартекс с двумя башнеобразными купольными компартиментами по бокам [10, с. 138-152; 17, p. 575-576] (Илл. 100). Прямоугольный объём экзонартекса замыкает композицию собора, объединяя за общей «ширмой» и саму церковь, и пристроенную к ней с севера лестничную башню. Центральная часть экзонартекса представляет собой двухэтажную галерею, открывающуюся аркадами: в нижнем ярусе две двойные арки фланкируют массивную трёхпро- 
летную, в аркаде второго яруса четыре трёхпролетные арки на тонких колонках чередуются с простенками, заполненными скруглёнными нишками, повторяя заданный мотив в более лёгких и изящных пропорциях. Ярусы разделены рядом расставленных в частом ритме небольших плоских нишек, заполненных кирпичным декором. Оформление башнеобразных приделов отражает в чистом виде стилистическую парадигму Эпира: призматические массивные объёмы с гладкими неразработанными фасадами, украшенными поясками простых кирпичных орнаментов, на уровне второго этажа появляются характерные широкие плоские ниши со вписанными в них трёхлопастными арками, обрамляющими оконные проёмы. Гранёные барабаны с уступчатыми арками, кирпичная ктиторская надпись, венчающая главный фасад, техника кладки клуазоне также обусловлены влиянием эпирской традиции. Стилистически экзонартекс полностью соответствует тенденциям заключительной фазы развития архитектуры Эпира, где прямой аналогией ему служит церковь Паригоритиссы в Арте (1294-1296), откуда, вероятно, и пришли мастера [18, р.132-133]. Помимо общности в трактовке формы, в фасадном декоре, оба памятника отмечены влиянием западноевропейской архитектуры: фасады Паригоритиссы, как неоднократно отмечалось, напоминают итальянские палаццо Проторенессанса, тогда как экзонартекс Св. Софии можно сопоставить, например, с фасадом венецианского палаццо Фондако деи Турки (XIII в.) на основе общности композиции с применением двухъярусной открытой аркады. В контексте палеологовского зодчества экзонартекс Софии Охридской имеет особое значение, так как относится к очень редкому для византийской архитектуры типу нартексов, которые шире самого храма и представляют собой «парадный фасад». Единственный аналогичный пример, близкий охридскому экзонартексу по времени, по характеру объёмно-пространственной композиции и по решению фасадов - экзонартекс Килисе Джами (нач. XIV в.) [14, с. 233-262]. Обстройка основного объёма периферийными зонами, открывающимися в экстерьер аркадами, - одна из тенденций архитектуры высокопалеологовского периода, заданная Константинополем [20, р.299-309]. Показательный пример - церкви Свв. Апостолов (1310-1314 гг.) и Св. Екатерины (1315-1320 гг.) в Салониках, где связь с архитектурой Константинополя всегда была прочна. Таким образом, экзонартекс Св. Софии Охридской представляет новую ступень развития эпирской традиции уже за пределами деспотата, где достижения зодчества Эпира конца XIII в. синтезируются с актуальными тенденциями высокопалеологовского зодчества столичного круга.

В 1334 г. Охрид входит в состав Сербского королевства и постепенно теряет своё значение. С этого времени вектор развития архитектуры меняется: линия репрезентативных построек 1280-1310-х гг. сменяется маргинальным направлением, представленным маленькими грубо сложенными однонефными базиликами, лишёнными фасадного декора. В отдельную подгруппу стоит выделить церкви Св. Богородицы Больничной (ок. 1360) [7, с. 130-131; 15, с.37-43], Свв. Константина и Елены (1368/кон. XIV в.) [15], а также частично сохранившуюся церковь Св. Георгия в Годивье [15, с. 45]. Они представляют собой сокращённый вариант типа ставроэпистегос, где поперечный неф инкорпорирован в цилиндрический свод основного зального объёма, и таким образом обозначают хронологические границы и степень ассимиляции эпирской традиции в поздневизантийской архитектуре Охрида. 
Необычной в таком архитектурном контексте представляется церковь Богородицы Заумской, построенная в 1361 г. Гргуром, сыном севастократора Бранко Младеновича [7, с. 141-143; 9, с.243-258; 17, р.576]. Морфологические и декоративные характеристики церкви со всей очевидностью следуют архитектурной парадигме Эпира последней трети XIII в., и более того, архитектурная иконография, композиция фасадов, декоративная программа обнаруживают близкое сходство с охридской церковью Перивлепты. Однако композиционные характеристики отличны от эпирской линии конца XIII в. и, как мы полагаем, возникают под влиянием сербских аристократических задужбин округа Скопье 1330-1390-х гг: вертикализм пропорций, камерность и дробность пространства, стремление к созданию компактного кубического объёма - всё это соответствует тенденциям архитектуры зрелого XIV века, реализованным в этой группе памятников. Таким образом, Заумскую церковь мы предлагаем рассматривать как пример локального ретроспективизма: ориентация на Перивлепту присутствует на уровне воспроизведения иконографии архитектуры и декоративной программы, но композиционные характеристики разделяют тенденции архитектуры 1330-1390-х гг.

В контексте архитектуры Охрида следует рассматривать и церковь Св. Димитрия в Велесе (кон. XIII в.) [10, с. 69-83], которая относится к довольно редкому типу - однонефная сводчатая базилика с нартексом, надстроенным ярусом колокольни (Илл. 101). Влиянием какой архитектурной традиции обусловлено появление этого типа на территории Охридской архиепископии, до конца не ясно, но декорация фасадов соответствует эпирским и охридским моделям: основной объём опоясан псевдомеандром и широким фризом опус ретикулатум, который продолжается и в центральной слепой арке трёхгранной апсиды. Тот же приём был использован в Перивлепте, которая, по всей видимости, была значимым местным ориентиром, и мы можем предположить, что в Велесе работала артель из Охрида.

Другим активным архитектурно-художественным центром на северных окраинах Византии стал Прилеп. Этот небольшой город был значимым торговым и политическим центром, который в течение XIII в. переходил из рук в руки между правителями Болгарии, Эпира и Никеи, а в 1280-е гг. с началом экспансии Сербии стал форпостом на сербско-византийской границе [13, с.79-82]. Во второй половине XIII в. здесь также появляются эпирские мастера, однако в отличие от Охрида, в Прилепе они имели дело главным образом с перестройкой и модификацией более ранних местных построек.

Показательным примером служит церковь Св. Димитрия, которая имеет сложную строительную историю. Мы будем опираться на реконструкцию С. Коруновского, который выделяет четыре строительных фазы [10, с. 153-166]. К изначальному зальному храму XII в. после 1246 г. с севера был пристроен открытый притвор с апсидой, обнаруживающий влияние архитектуры Никейской империи. Затем, в третью четверть XIII в., притвор заложили и надстроили, превратив церковь в двухнефный ставроэпистегос (Илл. 102). Эта фаза, безусловно, связана с работой мастеров из Эпира: кроме специфической типологии, маркерами эпирской традиции выступают трёхлопастные слепые арки, помещённые в рукавах трансепта, треугольные фронтоны, техника кладки, обрамленный плинфой поребрик. Похожие по форме и по исполнению трёхлопастные арки есть в верхних частях боковых фасадов западного купольного компартимента находя- 
щейся неподалеку церкви Св. Архангела Михаила [10, с. 107-133]. Сама церковь также имеет долгую строительную и реставрационную историю. Западный компартимент, датированный примерно 1280-ми гг, вероятно, был построен смешанной артелью с участием мастеров из Эпира, поскольку типология, пространственное решение, оформление свободных от декора фасадов мощными лопатками - черты, чуждые эпирской традиции.

В 1290-е гг. церковь Св. Димитрия перестроили с изменением типологии: с юга был добавлен ещё один неф, завершённый трёхгранной апсидой, а часть трансепта над центральным нефом заменена куполом на гранёном барабане, артикулированным аркадой (Илл. 102). В результате получилось подобие крестово-купольной структуры, что формально ставит церковь Св. Димитрия в один типологический ряд с первыми поздневизантийскими храмами Охрида. Асимметричная композиция, разновысотность сводов, как и сам акт вмешательства в готовую конструкцию с радикальным изменением типологии - всё это было известно строительной практике Эпира (достаточно вспомнить церковь Паригоритиссы или кафоликон Влахернского монастыря в Арте). Ей соответствуют также широкие ленты псевдомеандра и опус спикатум, проходящие по южному фасаду и апсиде, гранёный барабан купола с колонками по углам, артикулированный уступчатыми арками с подчёркнутыми фиалостомиями архивольтами. Различия в оформлении фасадов, в декоре, в профилировке трёхлопастных арок трансепта и слепой аркады барабана позволяют предположить, что две последние строительные фазы были результатом работы двух разных артелей из Эпира [6, с. 53-55].

Церковь Св. Николая (1298 г.) - однонефная сводчатая базилика без нартекса, построенная на основаниях более ранней [10, с. 38-61]. Фасады церкви полностью разработаны керамопластическим декором, организованным горизонтальными регистрами в соответствии с эпирской практикой (Илл. 103), однако в самом Эпире прямых аналогий этому памятнику нет. На боковых фасадах в центральное поле помещён мотив из трёх уступчатых слепых арок, фланкирующих небольшое окно. Архивольты подчёркнуты чередованием поребрика и поясков фиалостомиев. Сверху и снизу центральное поле обрамлено фризами геометрических орнаментов: двойной псевдомеандр, тройная ломаная линия, концентрические ромбы, фриз из треугольников, заполненных сверху раствором, а внизу оставленных открытыми. В исполнении декора можно отметить ряд характерных приёмов, свойственных работавшей здесь артели и ярко её характеризующих: двухуступчатые, не совсем ровные профилировки арок, использование камней треугольной формы, применение большого количества раствора, укладывание кирпича с небольшим выступом от плоскости стены, что придаёт пластичность и живописность трактовке фасадов. Тому же эффекту способствуют и многослойные архивольты арок, выложенные чередующимися ободками поребрика и фиалостомиев, «выемчатый» фриз из треугольников в верхней части северного фасада. Близкие характеристики в работе с декором в трактовке, в технике исполнения проступают в последней строительной фазе церкви Св. Димитрия (южный фасад, купол), а также в небольшой церкви Св. Петра, широко датированной к. XIII-XIV вв. [10, с. 62-68], что позволяет соотнести их с работой одной и той же эпирской артели [6, с. 53-55]. 
Итак, обобщая изложенные выше наблюдения, мы пришли к следующим выводам. Развитие архитектурной традиции Эпира в архитектуре Охрида и Прилепа не сводится к воспроизведению отдельных характерных элементов, но направляется тенденциями раннепалеологовского периода. В это время в византийской архитектуре происходит постепенный поворот от разнообразия решений и изощрённого декоративизма переходного периода (1204-1261) к формированию известной стилистической общности на основе унаследованных от предшествующих десятилетий архитектурных форм и средств [20, р.416-429]. В этом процессе поиска новой архитектурной выразительности проступают два направления. Первое, нацеленное на работу с самой формой, с её выражением, с композицией получает развитие в Константинополе, Салониках и в Охриде. Последний представляется весьма продуктивным региональным центром, реагировавшим на актуальные стилистические тенденции, где успели поработать как минимум три разных эпирских артели. Здесь утвердился тип одноглавого крестово-купольного храма на четырёх опорах, композиция объёмов отличается продуманностью, цельностью и гармоничностью, фасадный декор разнообразен, но подчиняется общим композиционным законам, ощущается переход от непредсказуемости, свойственной архитектуре первой половины XIII в., к упорядоченности и рафинированности вызревающего палеологовского стиля. Линия репрезентативной архитектуры 1280-1310-х гг. начинается от архаизированного храма Св. Иоанна Канео, затем продолжается в Перивлепте в варианте раннепалеологовского стиля, и завершается в экзонартексе Св. Софии уже во вполне сложившемся высокопалеологовском стиле, но в провинциальном, эпирском варианте. Отчетливой местной специфики в этих памятниках не прослеживается. Архитектура Охрида 1280-1310-х гг. - это эпирская традиция на этапе палеологовского стиля, воспринявшая ведущие тенденции - столичные и салоникские, и развивающая «классицизирующее» или «эллинистическое» направление, основанное на работе с архитектурными декоративными формами, их композиционными, пластическими и ритмическими возможностями.

Второе направление развития палеологовского стиля отталкивается от выразительных возможностей керамопластического декора, трактованного в «живописной», пластичной, экспрессивной манере, с учетом ритма, рисунка, светотеневых акцентов. Его появление можно проследить в Арте (нартекс церкви Св. Феодоры, церковь Св. Василия), а дальнейшее развитие - в Прилепе, где оно, как мы полагаем, подпитывалось и архитектурной традицией Никеи, так как прямых аналогий некоторые особенности работы с декором в памятниках Эпира не находят. Например, применение фиалостомиев, активная живописная разработка фасадов и прочие элементы декоративного арсенала церкви Св. Николая находят параллели в некоторых памятниках Никейской империи (Панагия Сикелия на Хиосе (XIII-XIV вв.)), а также южной элладской школы, повлиявшей на сложение архитектуры её окраин (Панагии Крина на Хиосе (1197)). О присутствии в Прилепе мастеров из Никеи свидетельсвует также северный фасад церкви Св. Димитрия. Однако вопрос о синтезе традиций Никеи и Эпира в архитектуре Прилепа конца XIII - начала XIV вв. требует дальнейшего углублённого изучения. Предстоит также выяснить происхождение и дальнейший путь следования двух идентифицированных эпирских артелей [6]. 
В завершение для полноты картины следует сказать и о специфике развития эпирской традиции в XIV в. на сербских территориях Северной Македонии, севернее линии Охрид-Прилеп-Штип: здесь она стала лишь одним из источников, повлиявших на архитектуру «сербско-византийского стиля», формировавшегося в рамках идеологической программы «византинизации» сербской культуры, инициированной кралем Милутином [2]. В постройках Милутина (церкви Св. Никиты в Чучере (1307 г.) [9, с. 15-36], Св. Георгия в Старо-Нагоричино (1312-1313)) [9, с. 37-80] традиции эпирской школы опосредованы преобладающим влиянием местных македонских образцов второй половины XIII в. и Салоник - ведущего к тому времени архитектурного центра на северных Балканах, где зодчество Эпира также было одним из источников формирования регионального архитектурного своеобразия наряду с Никеей и при сильном влиянии Константинополя [5; 17, p.545-558]. Характерные черты прослеживаются в основном в элементах фасадной декорации, отчасти сохраняются в пространственных, конструктивных и композиционных решениях.

Своего логического завершения ассимиляция эпирской традиции в Северной Македонии достигает в сербских вельможных задужбинах 1330-1390-х гг. - в памятниках так называемой «скопской школы» [16] (церкви Св. Архангелов в Штипе (1332), Спаса в Кучевиште (ок. 1332-1337), Св. Николая в Люботене (1337), Св. Архангелов в Лесново (1341), Успения Богородицы в Матеиче (ок. 1350), Св. Димитрия Маркова монастыря (1341-1371), Св. Андрея на Треске (1389)) [9, с. 129-142, 109-128, 151-188, 214-242, 275214]. «Эпирский след» можно различить в керамопластической декорации, которая, однако, к этому времени прочно входит в арсенал поздневизантийского зодчества и уже перестает напрямую идентифицироваться с Эпиром.

\section{Литература}

1. Бошкович Дж. Архитектура Сербии и Македонии // Всеобщая история архитектуры: в 12 т. Т.3: Архитектура Восточной Европы. Средние века. - М.: Изд-во литературы по строительству, 1966. C. 418-464.

2. Воронова A.A. Особенности «византинизации» сербской архитектуры в эпоху короля Милутина (1281-1321) // Вестник ПСТГУ. Серия V: Вопросы истории и теории христианского искусства. 2017. - Вып. 28. - С. 26-48.

3. Гусев Н. С. Македонский вопрос в освещении сербской и болгарской пропаганды в России в конце XIX - начале XX века // Актуальные проблемы теории и истории искусства: Сб. науч. статей. Вып. 10 / Под ред. А.В.Захаровой, С.В.Мальцевой, Е. Ю. Станюкович-Денисовой. - М.: МГУ им. М. В. Ломоносова; СПб.: НП-Принт, 2020. - С. 740-754.

4. Заворина М. Л. Палеологовское зодчество Салоник в контексте проблематики поздневизантийской архитектуры: историографический обзор // Актуальные рпоблемы теории и истории искусства: Сб. науч. статей. Вып. 10 / Под ред. А. В.Захаровой, С. В. Мальиевой, Е. Ю. Станюкович-Денисовой. - М.: МГУ им. М. В. Ломоносова; СПб.: НП-Принт, 2020. - С. 772-786.

5. Заворина М.Л. Фасадная декорация палеологовских храмов Салоник: специфика и эволюция локального метода // Studia Slavica et Balcanica Petropolitana. - 2020. - T. 28 - № 2. - C. 73-88.

6. Захарова A.B., Дятлова E.C. О строителях и художниках, работавших в македонском Прилепе в конце XIII века // Studia Slavica et Balcanica Petropolitana. - 2020 - T. 28 - № 2. - C. 46-72.

7. Злоковић M. Старе цркве у областима Преспе и Охрида // Старинар. - 1925. - С. 115-149.

8. Кондаков Н. П. Македония. Археологическое путешествие. СПб.: Отд. русского языка и словесности Императорской Академии наук, 1909. - 348 с. 
9. Кораћ В. Споменици монументалне српске архитектуре XIV века у Повардарју. Београд: ИГП Полиграф, 2003. - $341 \mathrm{c}$.

10. Коруновски С. Црковната архитектура во Македонија во XIII век. Докторска дисертација. - Скопје, 2000. -313 c.

11. Мальцева С.В. Храмовое зодчество Моравской Сербии и основные направления архитектуры палеологовского периода // Актуальные проблемы теории и истории искусства: Сб. науч. статей. Вып.7 / Под ред. А.В.Захаровой, С. В. Мальцевой, Е. Ю. Станюкович-Денисовой. - СПб.: Изд-во СПбГУ, 2017. С. 301-320.

12. Милковиќ-Пепек П. Црквата Св. Јован Богослов-Канео во Охрид // Културно наследство III. - Скопје, 1967. — № 4. - С. 67-124.

13. Прилеп и Прилепско низ историјата. Книга прва / Ред. М. Апостолски, Б. Бабиќ. - Прилеп: Издание на општинското собрание и на сојузот на здруженијата на борците од нов, 1971. -324 c.

14. Седов Вл. В. Килисе Джами. Столичная архитектура Византии. - М., 2008. - 336 с.

15. Суботић Г. Свети Константин и Јелена у Охриду. Београд: Филозофски факултет у Београду - Институт за историју ументности, 1971. - 144 с.

16. Bogdanović J. Regional Developments in Late Byzantine Architecture and the Question of 'Building Schools': An Overlooked Case of the Fourteenth-Century Churches from the Region of Skopje // Byzantinoslavica. - 2011. - Vol. 69/1-2. - P.219-266.

17. Čurčić S. Architecture in the Balkans from Diocletian to Süleyman the Magnificent. - New Haven, London: Yale University Press, 2010. - 913 p.

18. Čurčić S. The Epirote Input in the Architecture of Byzantine Macedonia and of Serbia Around $1300 / / \mathrm{A} \varphi \mathrm{t}$

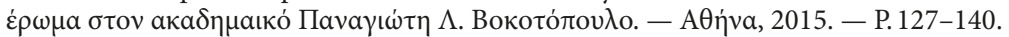

19. Hallensleben H. Die architekturgeschichtliche Stellung der Kirche Sv. Bogorodica Peribleptos (Sv. Kliment) // Musée Archéologique de Macédoine. Recueil des Travaux. - Vol. 6/7. - 1967-1974. — S.297-316.

20. Krautheimer R. Early Christian and Byzantine architecture. 4th ed. (revised by R. Krauthheimer and S. Ćurčić). New Haven, London, 1986.

21. Küpper H. M. Bautypus und Genesis der griechischen Dachtranseptkirche - Wien, 1996.

22. Maltseva S. V., Zavorina M. L. Late Byzantine Architectural Ceramics of Epirus and Macedonia // Proceedings of the International Conference SmartArt - Art and Science Applied. Faculty of Applied Arts, Belgrade, 2021. (in print)

23. Millet G. L'ancient art serbe. Les églises. — Paris: E. de Boccard Publ., 1919. — 208 p.

24. Nicol D. The Despotate of Epirus. Oxford: Blackwell, 1957. - 251 p.

25. Trkulja J. Aesthetics and Symbolism of Late Byzantine Church Façades, 1204-1453. Princeton, 2004. $378 \mathrm{p}$.

26. Velenis G. Thirteenth-Century Architecture in the Despotate of Epirus: The Origins of the School // Studenica et l'art byzantine au tour de l'annee 1200. - Beograd, 1988. - P. 279-284.

27. Vocotopoulos P. Church Architecture In the Despotate of Epirus: The Problem of Influences // Зограф. Београд, 1998-99. - № 27. - С. 72-92.

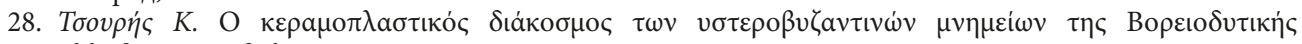

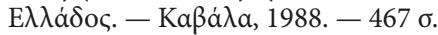

Название статьи. Эпирская традиция в поздневизантийской архитектуре Северной Македонии

Сведения об авторе. Заворина Мария Леонидовна - научный сотрудник. Филиал ФГБУ «ЦНИИП Минстроя России» Научно-исследовательский институт теории и истории архитектуры и градостроительства (НИИТИАГ), ул. Душинская, 9, Москва, Российская Федерация, 111024; Аспирант. Московский государственный университет имени М.В. Ломоносова, Ленинские горы, 1, Москва, Российская Федерация, 119991. marika_1096@mail.ru ORCID: 0000-0003-1652-1006

Аннотация. В статье рассматривается специфика ассимиляции архитектурной традиции Эпира в региональных центрах Северной Македонии - Охриде и Прилепе, а также на сербских территориях севернее линии Охрид-Прилеп-Штип. Стилистический и сравнительный анализ храмов Охрида и Прилепа в контексте архитектурных процессов XIII - начала XIV в. показывает, что присутствие эпирской школы здесь не ограничивается воспроизведением отдельных элементов, но направляется основными тенденциями палеологовского периода. Отсутствие выраженной локальной специфики даёт основание рассматривать поздневизантийскую архитектуру Северной Македонии второй половины XIII - первой половины XIV в. как последовательное продолжение эпирской традиции за пределами 
деспотата на этапе сложения палеологовского стиля, которое имело свои особенности в каждом из региональных центров. В Охриде архитектурные практики Эпира были интерпретированы с оглядкой на константинопольский вариант палеологовского стиля, выраженный в обращении к позднеантичным архитектурно-декоративным формам, в использовании их ритмических и пластических возможностей в создании общей композиции. В Прилепе получил развитие иной вариант стиля, где главным средством выразительности служит обилие и разнообразие фасадного декора. На сербских землях эпирская традиция растворяется среди других источников влияния в процессе формирования «сербско-византийской» школы.

Ключевые слова: византийская архитектура, Эпир, Северная Македония, Охрид, Прилеп

Title. The Tradition of Epirus in the Late Byzantine Architecture of North Macedonia ${ }^{2}$

Author. Zavorina, Maria Leonidovna - researcher. The Research Institute of Theory and Architecture and Urban Planning, Dushinskaya ul., 9, 111024 Moscow, Russian Federation; Ph. D. student. Lomonosov Moscow State University, Leninskie Gory, 1, 119991 Moscow, Russian Federation. marika_1096@mail.ru ORCID: 00000003-1652-1006

Abstract. The article examines the specificity of the assimilation of the architectural tradition of Epirus in the regional centers of North Macedonia - Ohrid and Prilep, as well as in the territories under the Serbian rule, north of the Ohrid-Prilep-Stip borderline. Stylistic and comparative Analysis of the churches of Ohrid and Prilep in the context of the architectural processes of the $13^{\text {th }}$-early $14^{\text {th }}$ centuries shows that the presence of the Epirote school here is not limited to the reproduction of individual elements, but is guided by the main trends of the Palaeologan period. The lack of pronounced local specificity gives reason to consider the Late Byzantine architecture of North Macedonia in the second half of the $13^{\text {th }}-$ first half of the $14^{\text {th }}$ century as a consistent continuation of the tradition of Epirus outside the Despotate at the stage of the formation of Palaeologan style.

Keywords: Byzantine architecture, Epirus, North Macedonia, Ohrid, Prilep

\section{References}

Apostolski M.: Babik B. (eds.). Prilep i Prilepsko niz istoriata. Knjiga prva (Prilep and Its Region Through the History. Part 1). Prilep, 1971. 324 p. (in Serbian).

Bogdanović J. Regional Developments in Late Byzantine Architecture and the Question of 'Building Schools': An Overlooked Case of the Fourteenth-Century Churches from the Region of Skopje. Byzantinoslavica, 2011, vol.69/1-2, pp. 219-266.

Boskovik Đ. Architecture of Serbia and Macedonia. Vseobshaya istoria arhitectury (Universal History of Architecture), vol.3. Leningrad, Moscow, Literature on Construction Publ., 1966, pp. 16-161 (in Russian).

Čurčić S. Architecture in the Balkans from Diocletian to Süleyman the Magnificent. New Haven; London, Yale University Press Publ., 2010. 913 p.

Čurčić S. The Epirote Input in the Architecture of Byzantine Macedonia and of Serbia Around 1300. Collection of Articles in Honor of Academician Panayotis L. Vocotopoulos. Athens, 2015, pp. 127-140.

Gusev N.S. The Macedonian Question in the Coverage of Serbian and Bulgarian Propaganda in Russia in the Late $19^{\text {th }}-$ Early $20^{\text {th }}$ Centuries. Actual Problems of Theory and History of Art: Collection of Articles, vol. 10. Moscow, MSU; St. Petersburg, NP-Print Publ., 2020, pp.740-754 (in Russian).

Hallensleben H. Die architekturgeschichtliche Stellung der Kirche Sv. Bogorodica Peribleptos (Sv. Kliment). Musée Archéologique de Macédoine. Recueil des Travaux, vol.6/7, 1967-1974, pp. 297-316 (in German).

Kondakov N. P. Makedoniia. Arkheologicheskoe puteshestvie (Macedonia: Archeological Journey). St. Petersburg, 1909. 348 p. (in Russian).

Korać V. Spomenici monumentalne Srpske arhitekture XIV veka u Povardarju (Monuments of Monumental Serbian Architecture of the $14^{\text {th }}$ Century in Povardarje). Belgrade, Poligraph Publ., 2003. 341 p. (in Serbian).

Korunovski S. Crkovnata arhitektura vo Makedonia vo XIII vek (Church Architecture in the $13^{\text {th }}-$ Century Macedonia), Ph. D. Thesis. Skopje, 2000. 313 p. (in Macedonian).

2 This study is based on the research, supported by the Program of Fundamental Research of the Russian Academy of Architecture and Construction Sciences and of the Ministry of Construction, Housing and Utilities of the Russian Federation - 2021, research project 1.1.1.2. 
Krautheimer R. Early Christian and Byzantine Architecture (revised by R. Krauthheimer and S. Curčić). New Haven, London, 1986. 553 p.

Küpper H. M. Bautypus und Genesis der griechischen Dachtranseptkirche. Wien, Verlag der Österreichischen Akademie der Wissenschaften Publ., 1996. 76 p. (in German).

Maltseva S. V. Churches of Moravian Serbia and the Main Directions of the Palaeologan Architecture. Actual Problems of Theory and History of Art: Collection of Articles, vol. 7. St. Petersburg, St. Petersburg University Press Publ., 2017, pp.301-320 (in Russian).

Maltseva S. V.; Zavorina M. L. Late Byzantine Architectural Ceramics of Epirus and Macedonia. Proceedings of the International Conference SmartArt - Art and Science Applied. Faculty of Applied Arts, Belgrade, 2021. (in print).

Miljkovik-Pepek P. Crkvata Sv. Jovan Bogoslov-Kaneo vo Ohrid. Kulturno nasledstvo, 1967, no. 3, pp.67124 (in Macedonian).

Millet G. L'ancient art serbe. Les églises. Paris, E. de Boccard Publ., 1919. 208 p. (in French).

Nicol D. The Despotate of Epirus. Oxford, Blackwell Publ., 1957. 251 p.

Sedov Vl. V. Kilise Camii. Stolichnaya arhitektura Vizantii (Kilise Camii. Mitropolitan Architecture of Byzantium). Moscow, Indrik Publ., 2008. 336 p.

Subotić G. Sveti Konstantin i Jelena u Ohridu (The Church of St. Constantine and Elena in Ohrid). Belgrade, Institute of Art History, 1971. 144 p. (in Serbian).

Trkulja J. Aesthetics and Symbolism of Late Byzantine Church Façades, 1204-1453. Princeton, 2004. 378 p.

Tsouris K. O keramoplastikos diakosmos ton isterobyzantinon mnimeion tis Voreiodytikis Ellados (The Ceramic Decoration of the Late Byzantine Monuments of Northwestern Greece). Kavala, 1988. 467 p. (in Greek).

Velenis G. Thirteenth-Century Architecture in the Despotate of Epirus: The Origins of the School. Studenica et l'art byzantine au tour de l'annee 1200. Beograd, 1988, pp.279-284.

Vocotopoulos P. Church Architecture in the Despotate of Epirus: The Problem of Influences. Zograf. Beograd, 1998-99, no. 27, pp. 72-92.

Voronova A. A. Features of "Byzantinization" in Serbian Architecture in the Time of King Milutin (12821321). St. Tikhon's University Review, Series 5: Problems of History and Theory of Christian Art, 2017, no. 28, pp. 26-48 (in Russian).

Zakharova A. V.; Dyatlova E. S. On the Builders and Painters Active in Prilep, North Macedonia, in the Late $13^{\text {th }}$ Century. Studia Slavica et Balcanica Petropolitana, 2020, vol.28, no. 2, pp. 46-72 (in Russian).

Zavorina M. L. Façade Decoration of Palaiologan Churches in Thessaloniki: Specificity and Evolution of the Local Approach. Studia Slavica et Balcanica Petropolitana, 2020, vol.28, no. 2, pp.73-88 (in Russian).

Zavorina M. L. Palaeologan Architecture of Thessaloniki in the Context of the Issues of Late Byzantine Architecture: Historiographic Review. Actual Problems of Theory and History of Art: Collection of Articles, vol. 10. Moscow, MSU; St. Petersburg, NP-Print Publ., 2020, pp.772-786 (in Russian).

Zloković M. Old Churches in the Areas of Prespa and Ohrid. Starinar, 1925, pp. 115-149 (in Serbian). 


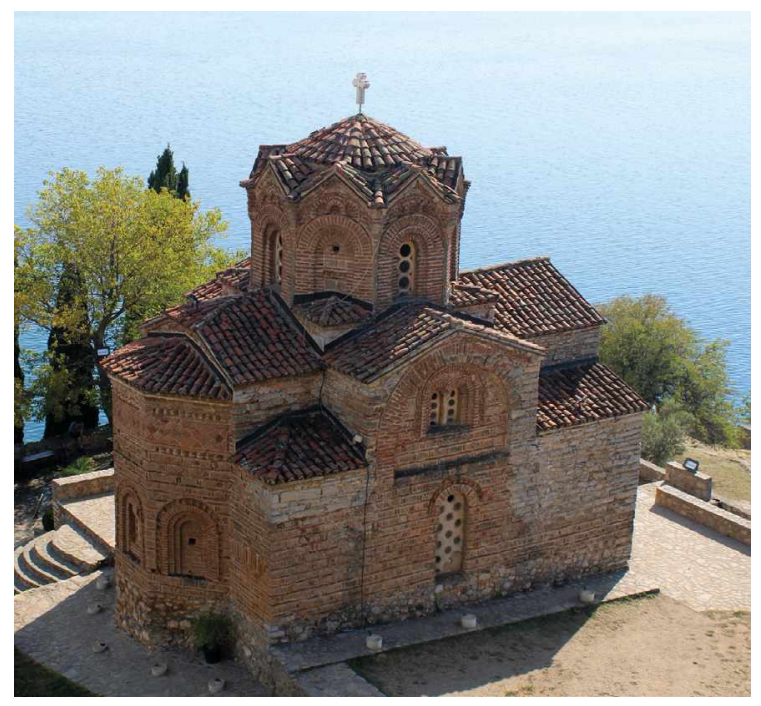

Илл. 98. Церковь Св. Иоанна Богослова Канео, Охрид, 1270-1280-е гг. Фотография М. Л.Завориной.

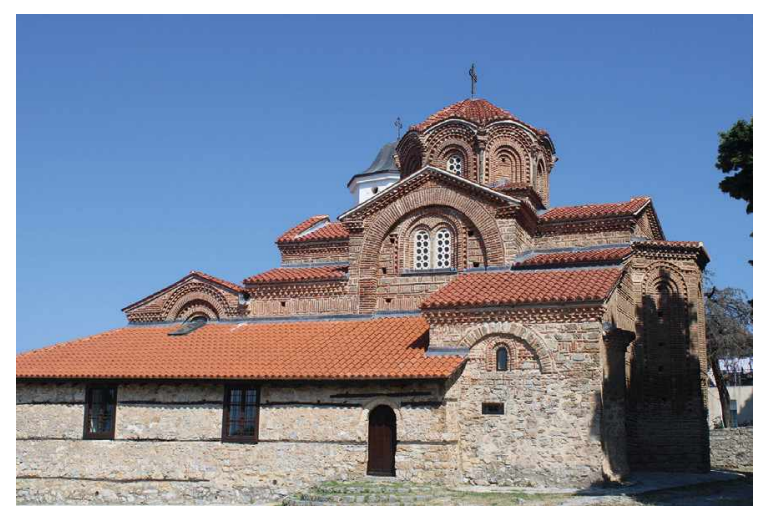

Илл. 99. Церковь Св. Богородицы

Перивлепты, Охрид, 1295 г. Фотография М. Л.Завориной

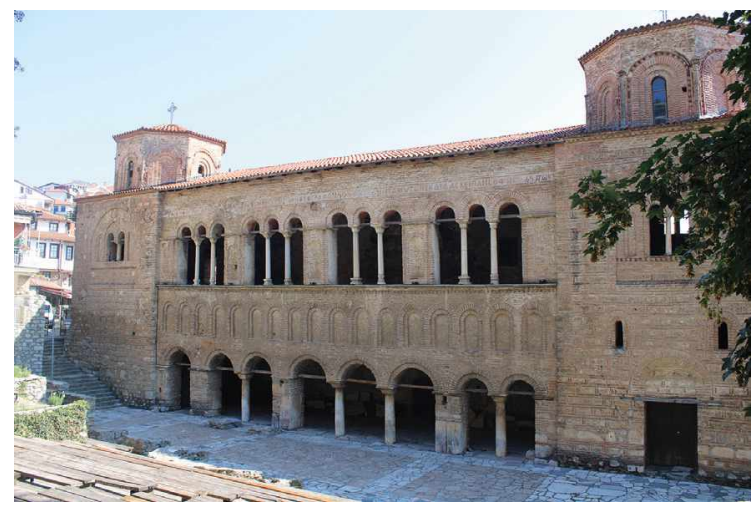

Илл. 100. Экзонартекс собора Св. Софии Охридской, 1310-1314 гг. Фотография М.Л.Завориной 

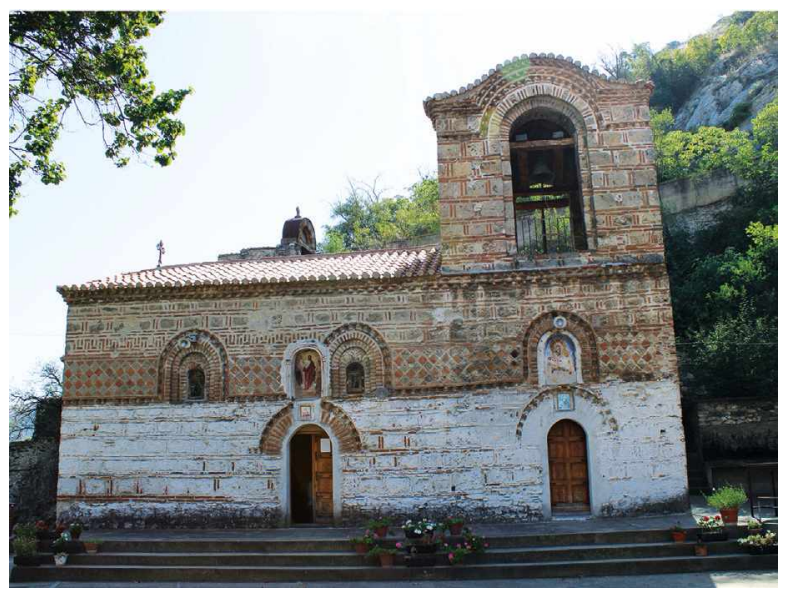

Илл. 101. Церковь Св. Димитрия, Велес, конец XIII в. Северный фасад. Фотография М.Л.Завориной
Илл. 102. Церковь Св. Димитрия, Прилеп. Северный фасад (3-я четверть XIII в.) и южный фасад (1290-е гг.). Фотография М.Л.Завориной
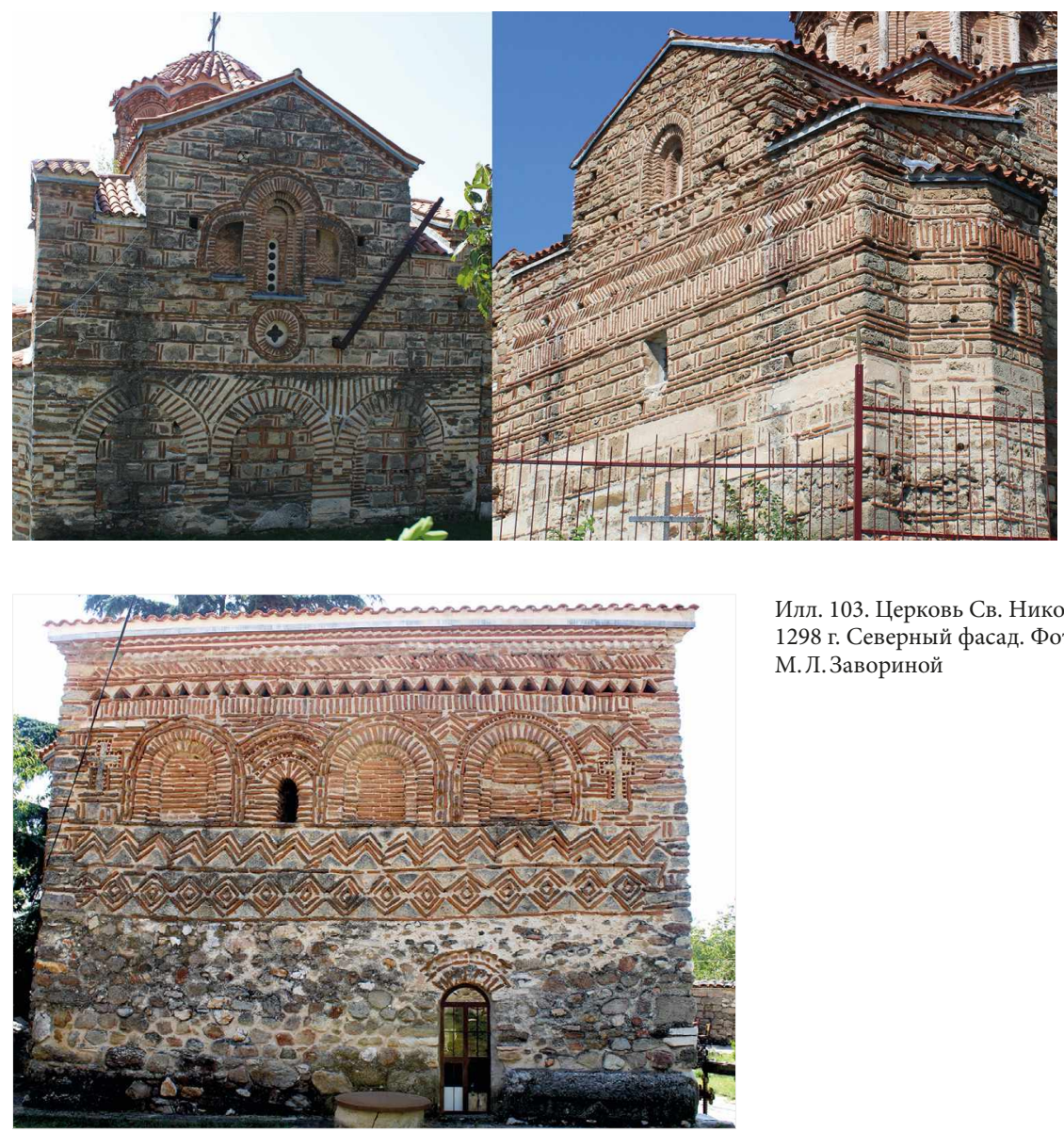

Илл. 103. Церковь Св. Николая, Прилеп, 1298 г. Северный фасад. Фотография М. Л.Завориной 